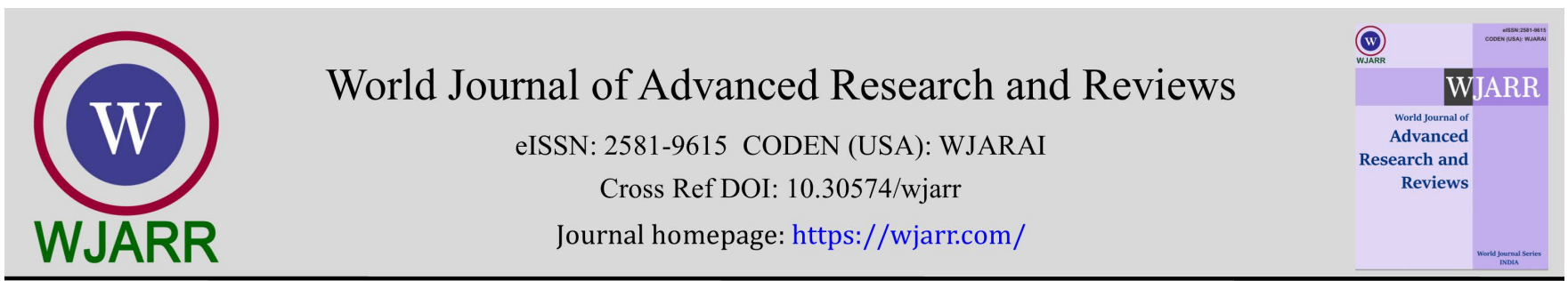

(RESEARCH ARTiClE)

\title{
Domestic solid waste generation and management in Hau My Bac A Commune, Cai Be District, Tien Giang Province, Vietnam
}

\author{
Nguyen Thanh Giao * \\ College of Environment and Natural Resources, Can Tho University, Can Tho 900000, Vietnam.
}

World Journal of Advanced Research and Reviews, 2021, 09(03), 020-026

Publication history: Received on 30 January 2021; revised on 27 February 2021; accepted on 01 March 2021

Article DOI: https://doi.org/10.30574/wjarr.2021.9.3.0078

\begin{abstract}
The study was conducted to survey the current situation of domestic solid waste generation and management in Hau My Bac A commune, Cai Be district, Tien Giang province in Hau My Bac A village, Cai Be district, Tien Giang province. Data on the status of generation and management were collected through direct interviews with 60 households and placed garbage bags in the households for a period of seven consecutive days a week. The research results showed that the average amount of domestic solid waste generated by each household was about 1-1.5 kg of waste/day, on average, each person generated $0.36 \mathrm{~kg} /$ person/day. The composition of domestic solid waste of households was relatively different, mainly organic waste, accounted for $47.88 \%$ higher than the other components. Plastic, plastic bags accounted for $24.65 \%$, metals $2.19 \%$, paper and carton $9.89 \%$, foam box accounted for $4.15 \%$. The wood, fabric, rubber, and glass were negligible. Hazardous wastes were not found in the study period. Currently, the collection was not met the demand of efficient solid waste collection due to the lack of facilities and the workforce. The rate of solid waste collection was only about 40-55\%. Local domestic solid waste managers have not been paid adequate attention to the overall management of solid waste. Local residents in the study area were not fully aware of the harms of domestic solid waste, did not actively participate in solid waste management activities leading to the difficulty in the management. The active participation of the community and strict enforcement of the environmental protection law can make an important contribution to the full management of solid waste in the study area.
\end{abstract}

Keywords: Domestic solid waste; Nylon; Organic wastes; Collection; Cai Be, Tien Giang

\section{Introduction}

Nowadays, when society develops to meet the needs and interests of people, people's lives are constantly improving, the environmental issue is always a highlight and needs attention of all countries in the world. Along with economic development, people's lives have been significantly improved. The higher people's living standard, the higher the demand for social products, which means an increase in domestic solid wastes [1]. Solid wastes generated in the process of eating, housing, production and consumption of humans, is increasingly discharged into the environment, exceeding the ability of the environment to self-clean, leading to a polluted environment. In Vietnam, the economy is on the way of developing, the lives of people are improved, more waste is generated. No activity in daily life does not generate wastes, in which, urban domestic solid waste generated about 38 thousand tons/day, rural area generated about 32 thousand tons/day. The rate of solid waste collection in urban areas reaches over $85 \%$, in rural areas about $45 \%$ to $50 \%$. However, the rate of solid waste treatment by landfilling accounted for $75 \%$ of the total amount of solid wastes generated annually [2]. Tien Giang is a coastal province in the Vietnamese Mekong Delta, which is located along the north of Tien River (a branch of Mekong River) with a length of $120 \mathrm{~km}$. The current capital of Tien Giang is My Tho City, $70 \mathrm{~km}$ south of Ho Chi Minh City and $100 \mathrm{~km}$ north of Can Tho city along National Highway 1A. Thanks to its very convenient location, Tien Giang has become the political and cultural center of the whole Mekong Delta, a very important

\footnotetext{
* Corresponding author: Nguyen Thanh Giao

College of Environment and Natural Resources, Can Tho University, Can Tho 900000, Vietnam..
} 
transit area linking the whole of the Southwest. Such a position helps Tien Giang soon become a province with the leading economic development in the southwestern region and the southern key economic region. In addition to the economic development, Tien Giang also has to face the problem of a growing population, which is one of the factors that reduce the quality of the environment and the increasing environmental pollution. Currently the amount of waste is increasing with more complex and diverse components. However, the remarkable thing is that there is no specific solution for the treatment of these generated waste sources. It is just waste collected in an open-air landfill, not treated, buried, unhygienic polluting air, soil and water environment [2]. In addition, the planning management has not been paid adequate attention, the awareness of the people is not high, leading to the waste environment is a concern of the environmental management agencies, leaders and people in the locality. The study was conducted to assess the current situation of domestic solid waste generation and management in Hau My Bac A commune, Cai Be district, Tien Giang province, from which solutions to environmental protection were proposed.

\section{Material and methods}

Data on current status and management of solid wastes were collected through interviewing 60 households living in Hau My Bac A commune, Cai Be district, Tien Giang province. The contents of the interview included the amount of domestic solid waste generated per day per person, how to handle waste in the households, waste classification at source, composition of solid wastes and collection fees. The management of domestic solid waste in the study area was assessed through the interviewing staff who are on the task of solid waste management of collection, transportation, management and treatment in Hau My Bac A commune, Cai Be district, Tien Giang province. Composition and volume of domestic solid waste were collected by placing garbage bags at the households to collect and classify the wastes. Every day, each household was given 2 different colored plastic bags, 1 bag for organic waste and 1 bag for other wastes. Each bag can hold $5 \mathrm{~kg}$ of domestic waste. The classification of waste was conducted under the guidance of Decree 38/2015/ND-CP, dated April 24, 2015 on waste and scrap management [3]. Solid wastes were classified at source in accordance with management purposes and handling. Accordingly, domestic solid wastes were divided into three groups. The biodegradable organic group included leftovers, leaves, vegetables, tubers, fruits and animal carcasses; group of reusable and recyclable included paper, plastic, metal, rubber, glass; and the other group.

After the waste was sorted and weighed, the percentage by weight was calculated by the formula:

$$
\% \text { each type of waste }=\frac{\text { individual type of waste }(\mathrm{kg})}{\text { total amount of } \text { wastes }(\mathrm{kg})} * 100
$$

The data collected was entered into excel to calculate the mean values and presented as tables or charts.

\section{Results and discussion}

\subsection{Current status of generation and domestic solid waste composition}

\subsubsection{General information about the interviewed households}

The interview results showed that among the interviewees, female accounted for $62 \%$ while male accounted for $38 \%$. With a higher rate of women than men in the total number of interviewed people, this was a group associated with domestic work and housework in the family. The averaged member in the family was members/household, aged 18 to 50 , and averaged at 35 years old. The respondents had the educational levels of primary, secondary, high school, college and university were $30 \%, 38 \%, 17 \%, 8 \%$ and $7 \%$, respectively. The interview results showed that the education levels of the interviewees in Hau My Bac A commune is still medium. In the survey of people living in the commune, the interviewees varied in occupations with workers, farmers, small traders, teachers, housewives, hired labor. Through the interviews with 60 households found that main occupation was housework (taking care of children, cooking), accounting for $43.3 \%$, farmers (rice and vegetable growing, fish and animal raising) accounting for $20 \%$. The rest accounted for $15 \%$.

\subsubsection{Household solid waste generation}

According to the survey data, the amount of daily household waste generated by the households was the lowest at 0.5 $1 \mathrm{~kg}$ and the highest was over $3 \mathrm{~kg}$. The amount of waste generated by each household was different depending on occupation, income level and living and production habits of the households. However, this main difference was the decisive level of income, from which a higher standard of living tended to generate more solid wastes. According to the research results, the amount of domestic waste generated from $0.5-1 \mathrm{~kg}$ accounted for $26.7 \%, 1-1.5 \mathrm{~kg}$ accounted for 
25\%, 3-3.5 kg and over $3.5 \mathrm{~kg}$ accounted for only 3.3\%. It showed that the amount of waste generated in households was relatively low.

\subsubsection{The amount and composition of household's solid wastes}

It can be seen that on average a household in the area generated $1.33 \mathrm{~kg}$ of waste. The highest amount of solid waste generated was $2.5 \mathrm{~kg} /$ household/day, and the lowest was $0.5 \mathrm{~kg} /$ household/day. The average amount of generated waste per person was about $0.36 \mathrm{~kg} /$ person/day. The amount of waste generated in each household was different due to the economic conditions, living habits, and occupation of the households. The composition of solid waste in the commune was mainly solid wastes, the rest was medical solid wastes, which accounted for a small proportion. Diverse solid waste composition included organic and inorganic. According to the results, there was a total of 37 people/ 10 households with a total waste weighing $81.9 \mathrm{~kg}$ in 7 days. On average, a household with 3 people would release about 1-1.5 kg/day. Thus, a person would generate about $0.33-0.5 \mathrm{~kg} /$ person/day. The results of the interviews from the commune People's Committee of Hau My Bac A commune, the whole commune has about 14,079 people, the amount of waste per day was about 5 tons/day, so on average, one person generates about $0.36 \mathrm{~kg} / \mathrm{person} / \mathrm{day}$. This number was in the range of the calculated amount of weight generated at each household. Table 2 showed that the amount of solid wastes in Mang Thit district (0.5-1 kg) and Vung Liem district (1-2kg) was relatively similar to the amount of solid waste in Hau My Bac A commune (1-1.5kg) in each household. The average amount of solid waste per person in Mang Thit district was $0.24 \mathrm{~kg} /$ person/day [4], in Vung Liem district was $0.258 \mathrm{~kg} /$ person/day [5] was not much difference with the average amount of solid wastes in Hau My Bac A commune ( $0.36 \mathrm{~kg} /$ person/day). The amount of waste generated in each household was different due to economic conditions, living habits, and occupation of households. The rate of solid waste collection in the study areas varied from 40 to 55\%. This collection rate was still quite low, mainly people treat the solid wastes by burying, burning and throwing the wastes on the street, into the river. The percentage of organic waste in Mang Thit district was quite high, accounting for 77.95\% [4], while in Vung Liem district accounted for 39.32\% [5] and Hau My Bac A commune occupied 47.88\%. The amount of organic waste was reused by people as food for animals or as fertilizer for crops, so it was difficult to accurately determine the amount of the organic wastes. It showed that the amount of solid wastes in the households was still relatively high with increasingly complex components, making it difficult for solid management while the collection and treatment had many limitations.

Table 2 Solid wastes generation rates at various localities

\begin{tabular}{|l|l|l|l|}
\hline & Mang Thit district [4] & Vung Liem district [5] & Cai Be district \\
\hline Amount of SW & $0.5-1 \mathrm{~kg} / \mathrm{hh}$ & $1-2 \mathrm{~kg} / \mathrm{hh}$ & $1-1.5 \mathrm{~kg} / \mathrm{hh}$ \\
\hline Generation rate & $0.24 \mathrm{~kg} / \mathrm{person} / \mathrm{d}$ & $0.258 \mathrm{~kg} / \mathrm{person} / \mathrm{d}$ & $0.36 \mathrm{~kg} / \mathrm{person} / \mathrm{d}$ \\
\hline Collection rate & $50 \%$ & $40-50 \%$ & $40-55 \%$ \\
\hline Organic waste & $77.95 \%$ & $39.32 \%$ & $47.88 \%$ \\
\hline Inorganic waste & $22.05 \%$ & $60.68 \%$ & $52.12 \%$ \\
\hline
\end{tabular}

Table 3 Composition of solid wastes at the study area

\begin{tabular}{|l|l|l|l|l|l|l|}
\hline \multirow{2}{*}{ No. } & \multicolumn{2}{l}{$\begin{array}{l}\text { Organic } \\
\text { (weight 39.2 kg accounted for 47.88\%) }\end{array}$} & \multicolumn{2}{l}{$\begin{array}{l}\text { Inorganic } \\
\text { (weight 42.7 kg accounted for 52.12\%) }\end{array}$} \\
\cline { 2 - 7 } & Composition & $\mathbf{W}$ & Rate (\%) & Composition & W & Rate (\%) \\
\hline 1. & Leftovers & 17.02 & 20.78 & Metal & 1.79 & 2.19 \\
\hline 2. & Vegetables & 8.40 & 10.26 & Foam box & 3.40 & 4.15 \\
\hline 3. & Peels & 6.70 & 8.18 & Nilon, plastics & 20.19 & 24.65 \\
\hline 4. & Leaves & 7.79 & 9.52 & Paper, carton & 8.10 & 9.89 \\
\hline 5. & & & & Wood & 1.82 & 2.22 \\
\hline 6. & & & & Glass & 1.62 & 1.98 \\
\hline 7. & & & & Rabric & 1.64 & 2.01 \\
\hline 8. & & & & snail shell & 2.20 & 1.50 \\
\hline 9. & & & & & 2.67 \\
\hline
\end{tabular}


The waste samples collected at the households showed that the total amount of waste was $81.9 \mathrm{~kg}$. The organic waste was $39.2 \mathrm{~kg}$, accounting for $47.88 \%$ with the highest proportion of cooked rice and leftovers $17.02 \mathrm{~kg}(20.78 \%)$. The amount of inorganic waste was $42.7 \mathrm{~kg}$. The amount of inorganic wastes was higher than that of organic wastes. Because part of organic waste (rice, leftovers, spoiled fruit) was used for livestock, therefore, the amount of organic matter was lower than that of inorganic waste. For recyclable and reusable components such as paper, nylon, plastic and metal were separated by some households for selling or recycling.

\subsubsection{Methods of waste management and treatment in households}

The results of interviewing the households in Hau My Bac A commune about the implementation of solid waste management showed that the households had a sense of environmental sanitation. Household waste was stored in open plastic bins and baskets (45\%), the rest was contained in plastic wrap (33\%). However, the proportion of households that did not have a waste container accounted for $22 \%$. This is a problem that needs attention, improper disposal would generate odors and have the ability to attract insects that cause pathogens that affect the health of the family in particular and the surrounding area in general. The current way of handling people was not suitable. With the characteristics of living in rural areas, the households living in narrow roads that was difficult to reach by collection trucks. For solid waste management in these households, people treated the wastes by burning accounted for up to $53.3 \%$.

\subsection{Current status of solid waste management in Hau My Bac A commune}

\subsubsection{Collection status}

Collection is the first step in solid waste management, so the collection is very important. The survey showed that the solid waste collection in Hau My Bac A commune has not been given adequate attention, most types of waste were mixed in the discharge process, which affects the solid waste management. Solid waste in the study area would be collected including all roads of the commune and solid wastes from households living in the area. The commune's solid waste was initially collected by pushcarts, followed by the waste being transferred from pushcarts to the temporary waste collection points. It will then be transported by a specialized garbage truck from the temporary garbage gathering point to the Tan Lap 1 landfill, Tan Phuoc. Solid waste collection in the commune is undertaken by the Urban Environment Limited Company. Solid waste collection and transportation vehicles (garbage compactors, public trash) were invested by the Department of Natural Resources and Environment of Cai Be district, Tien Giang. Currently, due to limited equipment, the workforce was inadequate solid waste collection workers and the transport constraints in rural areas, the waste collection in the commune was not completely good.

\subsubsection{Collection time}

The solid waste collection system in Hau My Bac A commune only included markets, shops, businesses, schools and households near the market. The collection vehicle followed a predetermined route with a stable time. Every day, the pickup truck works from 5:00 p.m. to 7:00 p.m. Collection was not stable, due to lack of means and labor force for the collection. Solid waste in Hau My Bac A commune, when being collected, was not classified at source, but directly put it in the garbage truck. Garbage from households was collected with a pushcart of $0.25 \mathrm{~m} 3$. When the garbage track was fully collected, the collectors transported the garbage to Tan Lap 1 landfill in Tan Lap district, Cai Be province.

\subsubsection{Collection fee}

Solid waste collection fee in Hau My commune, Bac A was implemented in accordance with Decision No. 27/2018/QDUBND dated December 20, 2018 of People's Committee of Tien Giang Province [6]. 
Table 1 Service charge for collection and transportation of domestic solid waste

\begin{tabular}{|l|l|l|l|}
\hline No. & Object/Transport distance & Unit & Maximum price \\
\hline 1. & Individuals, households & VND/hh/month & 20.000 \\
\hline 2. & Rent room & VND/room/month & 15.000 \\
\hline 3. & $\begin{array}{l}\text { Individual business households (not including } \\
\text { households doing catering, food, fruit and vegetable } \\
\text { shops) }\end{array}$ & VND/hh/month & 30.000 \\
\hline 4. & $\begin{array}{l}\text { Schools, kindergartens, administrative agencies, non- } \\
\text { business units (not including hospitals), police, } \\
\text { military, corporate offices (not including production } \\
\text { facilities) }\end{array}$ & $\begin{array}{l}\text { VND/unit/month } \\
\text { manufacturing facilities (including fruit and vegetable } \\
\text { granaries), businesses, markets, docks, bus stations } \\
\text { and construction site }\end{array}$ & 140.000 \\
\hline 5. & $\begin{array}{l}\text { Transport distance within 25 km } \\
\text { Transport distance from 25 km to 65 km }\end{array}$ & VND/ton of solid waste & 182.000 \\
\hline 5.2. & $\begin{array}{l}\text { VND/ton of solid waste } \\
\text { Traps, }\end{array}$ & 380.000 \\
\hline
\end{tabular}

\subsubsection{Current management}

Solid waste, after being collected, was transported by specialized trucks to Tan Lap 1 landfill, Tan Phuoc district, Tien Giang province. According to information from the Department of Construction of Tien Giang province, the whole province currently has eight operating landfills, but most of the landfills treat the waste by dumping wastes. Some landfills were in a state of overload, without complete leachate treatment system. The leachate was only treated by biological reservoirs which could be easy to spill out in the rainy season. The two largest landfills located in the eastern and western areas of Tien Giang province were having problems with environmental treatment. It was the landfill of Long Chanh commune (Go Cong town) in the east and the landfill of Tan Lap 1 commune (Tan Phuoc district) located in the west of the province. Long Chanh commune landfill had a size of more than 5.5 ha, received about 70 tons of solid wastes/day, but treatment facilities were improper. Tan Lap landfill was the largest landfill in Tien Giang province, managed by My Tho Urban Construction One-member Limited Company. With a scale of 14.88ha, the landfill capacity of this landfill was only 180 tons/day, but every day this landfill must receive about 350 tons of garbage because it not only handled the solid wastes for My Tho city, but also for the solid wastes from the districts of Cai Be, Cai Lay, and a part of Cho Gao district. Currently, this landfill treated the solid wastes by landfilling method combined with deodorizing spray, with biological pond to prevent spillage of leachate. However, when heavy rain, water overflow caused odor and affected the environments. The smell of gasses, and the leachate of solid wastes from transport vehicles caused trouble for many people, even though they were miles from the landfill. Currently, this landfill was overloaded causing environmental problems. Recently, this landfill has caught fire continuously spreading bad odors to nearby households. Although the functional force regularly put down the fire, the smoldering phenomenon still lasted all the time. Particularly, a fire occurred at the landfill due to long-term persistence of methane in the landfill, causing spread of fire. Currently, the rate of the collection in the province was about $40-55 \%$. The treatment methods in the households were mainly burning, burial, and disposing of solid wastes directly into the street or into the river. Sorting solid waste was the next step in solid waste management, waste classification played an important role in solid waste management, contributing to minimizing the risk of spreading pathogens, toxic factors. The correct classification also contributed to saving resources, reducing costs for waste collection and treatment. The purpose of solid waste classification was to separate the waste components according to the physical, chemical or biological properties to recover, recycle or to choose appropriate measures to treat the wastes. The actual survey results showed that the solid waste classification in the commune has not been implemented. Specifically, in the whole area, only one type of waste bin was placed for all types of wastes. The classification of solid wastes was usually conducted right at home, depending on family circumstances. In the composition of domestic solid waste, households have collected, partially classified and separated the types of waste that can be sold or reused such as paper, metal, plastic bottles. However, this amount was not much. Organic wastes such as leftovers, spoiled vegetables were used by families as food for livestock. Other unused solid wastes were not classified but for mixing, including those that were biodegradable (leaves, animal carcasses) and persistent (glass, nylon, plastic) and even hazardous waste (batteries, batteries, fluorescent lights). For people living in narrow roads, they had to bring garbage to temporary gathering points, but at present there was no household putting 
their wastes on those points. Alternatively, the household mainly released the wastes onto the streets, gardens, or into the river. As can be seen that, the solid wastes were treated improperly by the households. This could lead to serious environmental pollution

\subsection{Domestic solid waste management solutions in Hau My Bac A commune}

\subsubsection{Solid waste classification at source}

Classification of solid waste at source is very important [7] and this work could help waste owners making use of reusable and recyclable wastes, creating favorable conditions for the treatment process. Sorting helps to recover reusable matters, recycles and separates the biodegradable components for composting, which can reduce the amount of solid waste to landfill, and at the same time reduce the risk of epidemic spread from domestic waste. The separation of waste at source by directly dividing solid wastes into two groups by waste source owners. Group 1 included biodegradable organic waste with the main composition of food waste (except for shells, clams, food packaging of all kinds). Group 2 included all remaining garbage components. Specifically, types of paper and carton packaging (group 2a); Packaging and articles of metal, plastic, glass and rubber (group 2b); Battery cells, batteries, fluorescent lamps, lubricant wipes (group 2c) and the remaining components (group 2d). The initial activity was to propagate, call, and guide people to sort solid wastes on the mass media. Then set up a group of volunteers to distribute plastic bags and trash cans to the households and instruct people how to classify solid wastes. The next step is to expand the sorting area. Encourage people to continue sorting, depending on the specific conditions of each source, can equip additional types of containers, plastic bags to proceed to group 2 above out into more forms of composition (Group 1 should remain the same). Plastic bags and green plastic containers with lids were used to store biodegradable waste. Plastic bags and orange plastic containers were used to store the remaining solid wastes. In the households, it was good to use plastic bags and $10 \mathrm{~L}$ waste containers. At the market, solid wastes stored in plastic bags then brought to $240 \mathrm{~L}$ waste bins that had been placed along the market corridor. The $660 \mathrm{~L}$ waste bins were used to gather the collected solid wastes. For public areas, streets need to be equipped with $120 \mathrm{~L}$ waste bins, placed on the main street axes, the distance between 2 waste bins was $100 \mathrm{~m}$. the truck was also equipped with several compartments to store the separated wastes.

\subsubsection{Proposal to improve the solid waste collection frequency}

For the frequency of collection, biodegradable organic waste should be collected once a day and for recyclable waste 3 times/week. Because easily biodegradable organic waste accounted for a large proportion in solid composition and if stored in the household for a long time, it would generate odors, flies, affecting people's health, so it was necessary to collect once/day. The remaining wastes rarely generated bad odors, so being stored at source for several days can save transportation costs. Regarding means of domestic solid waste collection and transportation, there should have more waste bins for various waste types and more trucks with separated compartments for each type of wastes classified. Government and private sectors could join in solid waste management to enhance the efficiency of solid waste management.

\subsubsection{Raising public awareness}

Solid waste management required the participation of the community, so raising community's awareness about solid waste played a fundamental role in making the management plan easy and quick. The target groups should be workers in the area of all ages and different professions. Constructing and implementing communication campaigns to raise public awareness in schools, business establishments by the means such as television, radio, newspapers, banners, with directional content. Incentives to encourage the participation in waste separation at source, reduce, recycle, reuse solid waste, limit the use of plastic bags, and properly dispose of garbage is urgently needed. Strengthening the propaganda of legal documents, policies and regulations on environmental protection for people to know and implement, organize propaganda sessions to use recycled products, limit the use of plastic or reuse many times, encourage the use of biodegradable bags is necessary. Establishing professional groups to propagate to each household to guide and support people in disposing of garbage in the right place, sorting garbage, how to handle garbage at home. At the same time, placing environmental education activities into the lessons at all educational levels. The functional agencies should intensify the inspection of waste collection and treatment to promptly handle violations of environmental sanitation.

\subsubsection{Solutions for strengthening management capacity}

This study suggested that the solid waste management system should be enhanced. Environmental officers need to be trained to improve professional qualifications. There should have some exchange with experts to learn experience, improve skills in solid wastes management, and to have sufficient knowledge to receive transfer new and advanced technologies for solid waste treatment. The government should be responsible for the payment of the costs for strengthening capacity of the solid waste managers 


\section{Conclusion}

The results indicated that the average amount of solid waste generated was $0.36 \mathrm{~kg} / \mathrm{person} / \mathrm{day}$. Solid waste composition of the households was relatively different, biodegradable components accounted for $47.88 \%$. Plastic, plastic bags accounted for $24.65 \%$, the remaining component such as wood, fabric, rubber and metal accounted for a negligible proportion. There was no hazardous waste during the study period. Currently, the rate of the collection in the province was about 40 - 55\%. The treatment methods in the households were mainly burning, burial, and disposing of solid wastes directly into the street or into the river. Currently, due to limited equipment, the workforce was inadequate solid waste collection workers and the transport constraints in rural areas, the waste collection in the commune was not completely good. The classification at source and more investment on waste collection and treatment are urgently needed to solve the solid waste management problems in the study area.

\section{Compliance with ethical standards}

\section{Acknowledgments}

The author would like to thank you for the supports from students and staff from the College of Environment and Natural Resources, Can Tho University, Vietnam.

\section{Disclosure of conflict of interest}

There is no conflict of interest to declare.

\section{References}

[1] Department of Natural Resources and Environment of Ho Chi Minh City. Report on solid waste treatment planning in Ho Chi Minh City. 2018.

[2] Northern Center for Environmental Monitoring - General Department of Environment. Current situation of solid waste collection and treatment in Vietnam. 2018.

[3] Government Decree. Decree 38/2015/ND-CP, on waste and scrap management. 15 April 2015.

[4] Nguyen Thi Quyen Trang. Current situation of rural waste management and treatment in Mang Thit district, Vinh Long province. Graduation thesis, Can Tho University. 2014.

[5] Truong Anh Kim. Current assessment of domestic solid waste management in Vung Liem district, Vinh Long province. Graduation thesis, Can Tho University. 2017.

[6] People's Committee of Tien Giang Province. Decision No. 27/2018/QD-UBND. Decides on the regulations on assessment of domestic waste collection and transportation services in the province of Tien Giang. 20 December 2018.

[7] National Assembly. Law No. 55/2014/QH13. Law on Environmental Protection. 23 June 2014. 